\title{
Thermodynamics of supramolecular systems: Recent developments
}

\author{
Angela F. Danil de Namor \\ Laboratory of Thermochemistry, Department of Chemistry \\ University of Surrey, Guildford, Surrey, GU2 5XH, UK
}

\begin{abstract}
Thermodynamic aspects of Supramolecular Chemistry are presented. These include solubility properties of calix(n)arenes and their ester derivatives in various solvents. Particular attention is drawn to the effect of: i) "allosteric guests" (reaction media) on the binding properties of calixarene esters toward alkali metal cations; ii) cyclodextrins on the transfer of drugs from water to chloroform.

A brief introduction on the role of macrocyclic ligands for the design of new materials is given. An initiative to encourage research on the thermodynamics of new electrolytes and non-electrolytes originating in the developments in the area of Supramolecular Chemistry is suggested.
\end{abstract}

\section{INTRODUCTION}

Lehn (ref. 1) in his Nobel lecture in 1987 stated that "Supramolecular Chemistry is the chemistry of the intermolecular bond, covering the structures and functions of entities formed by the association of two or more chemical species". A direct implication of this statement is that if the intermolecular interactions taking place in solution processes are to be understood, the thermodynamic characterisation of these systems must be considered.

The developments in the area of Supramolecular Chemistry since the late sixties are mainly on the synthetic and structural aspects of macrocyclic chemistry. The contributions made on the thermodynamics of these systems are included in a series of review articles published by Izatt and coworkers (refs. 2-4), in which stability constants ( $\log K_{s}$ ); enthalpies $\Delta_{c} H^{\circ}$ and $\Delta_{c} \mathrm{~S}^{\circ}$ of complexation of macrocyclic ligands with metal and organic cations in a wide variety of solvents are listed. The latest one (ref. 4), published in 1991, covers the literature until 1990 . It must be said that a good reproduction of thermodynamic data is still far away, often due to the unsuitability of the methods used or by oversimplifications made in the derivation of such data. There is now the need for a critical evaluation of existing data in order to produce a set of recommended data. The basis to proceed with such an evaluation has been provided by the pioneering work of Izatt et al. Even though some progress has been made on the thermodynamics of binding processes involving macrocyclic ligands and cations, a lot remains to be done. It seems appropriate to mention that, in spite of the biological interest attached to these ligands, most of the thermodynamic data are referred to the standard temperature $(298.15 \mathrm{~K})$. In addition, there are two important aspects of thermodynamics which have been hardly considered. These are:

i) The solution thermodynamics of macrocyclic ligands and their metal ion complexes. It must be recognised that the synthetic developments in this area have resulted in a large variety of non-electrolytes (neutral macrocyclic ligands) which upon complexation with organic and metal ion salts results in a wide variety of new electrolytes. Despite that the solution thermodynamics of these novel chemical entities can enlighten our present knowledge on electrolyte and non-electrolyte solutions, very few efforts have been directed to characterise these systems.

ii) Heat capacity measurements. In spite of the useful information that can be obtained from the availability of these data, particularly for processes in aqueous solutions (ref.5) the amount of research done in this area is indeed very limited. The lack of contributions on this particular aspect of thermodynamics has been previously noted by Izatt et al (ref.4). 
Our interest is currently focused on binding processes involving macrocyclic ligands with neutral and ionic species in solution, as well as on the solution thermodynamics $\left(\Delta_{8} G^{\circ}\right.$, $\Delta_{\mathbf{s}} \mathrm{H}^{\circ}$ and $\Delta_{\mathrm{S}} \mathrm{S}^{\circ}$ ) of the individual entities taking part in these processes. Solvation plays an essential role in the binding of these systems and therefore, the differences in solvation of a solute (host, guest and host-guest complex) in two solvents as reflected in the transfer thermodynamic parameters $\left(\Delta_{t} G^{\circ}, \Delta_{t} H^{\circ}\right.$ and $\left.\Delta_{t} S^{\circ}\right)$ must be considered in order to elucidate some of the main features characterising host-guest interactions (refs.6-11) in solution.

The research interests at Surrey include

a) The use of azamacrocyclic ligands for the selective extraction of copper from aqueous solutions. The introduction of lipophilic groups in the basic structure of dioxocyclam 1 (ref.12) was done to reverse its solubility in such a way as to make these substituted ligands 2 highly soluble in organic solvents (particularly those for which direct partitioning with water could be achieved) and slightly soluble in water so their use in solvent extraction technology could be explored. However, the final aim of this work is the design of new polymeric materials. To facilitate polymerisation without affecting the binding properties of these ligands, suitable groups are introduced in their structure 3 so these copper selective compounds can be incorporated as anchor groups in these new materials (ref.13).

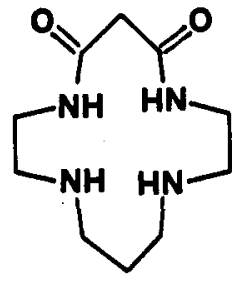

1

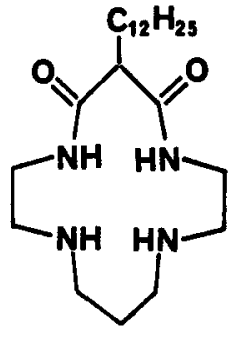

$\underline{2}$

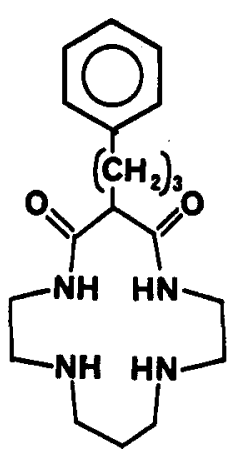

$\underline{3}$

b) The selection of new macrocyclic electrolytes for use in high energy lithium batteries (ref.14).

c) Thermodynamic aspects of calixarene chemistry covering:

1. Proton transfer reactions between amines with phenol 4 and resorcinol 5 based calixarenes with the aim of formulating a selective method for amine separations (refs.15 \& 16).<smiles>CCCCCCCCc1cc(O)cc(C(C)(C)C)c1C(C)(C)C</smiles>
$n=4,6,8$

$\underline{4}$<smiles>[R]C(C)c1cc(C)c(O)cc1O</smiles>

$\underline{5}$

$$
\mathrm{R}=\left(\mathrm{CH}_{2}\right)_{10} \mathrm{CH}_{3}
$$<smiles>Cc1cc(O)cc(CCC(C)(C)C)c1C(C)(C)C</smiles>

$\underline{6}$<smiles>[R]#CCC(=O)OCC</smiles>

2. The use of calixarenes as drug receptors (ref. 17).

3. Complexation of calixarene derivatives 6 with metal and organic cations in non-aqueous solvents (refs. 18 \& 19). 
d) The effect of cyclodextrins 7 on the transfer of drugs from water to membranelike solvents (ref. 20) as well as the interactions of these ligands with monosaccharides (ref. 21) in aqueous medium.

In this paper, thermodynamic aspects of calixarene chemistry are first discussed. This is to be followed by recent work on the effect of cyclodextrins on the transfer of drugs from water to membrane-like solvents. Finally, an outline is given about the use of macrocyclic ligands for the design of new materials.

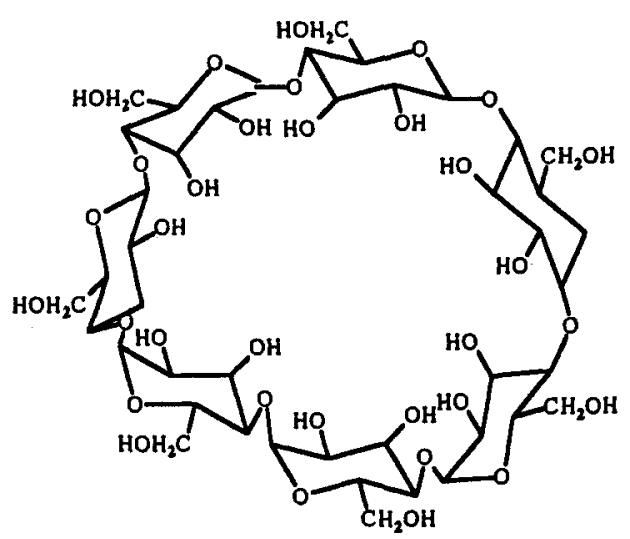

$\beta$-cyclodextrin 7

\section{THERMODYNAMICS ASPECTS OF CALIXARENE CHEMISTRY}

\section{p-tert-butyl calix(n)arenes: solubility data}

Although the history of calixarenes dates back to the work of von Baeyer (ref.22) in the last century and their synthesis by Zieker and coworkers in 1944 (ref.23), interest in the field of calixarene chemistry took off with the work of Gutsche and coworkers (refs.24-26) and has grown extensively ever since. Calixarenes are obtained by condensation reaction between $p$-substituted phenol and formaldehyde 4. Lying between the aromatic rings is a hydrophobic cavity able to interact with neutral species forming molecular complexes. Their scope to transport selectively univalent cations from alkaline solutions to membrane-like solvents was first noted by Izatt and coworkers (refs.27 \& 28). The process taking place in this selective transport involves the formation of a neutral complex (calixarenate anion and metal cation) and the release of a proton. Metal derivatives of calix(n)arenes have been reported by several workers (refs.29-40). Although it has been often mentioned that calix $(n)$ arenes are characterised by a relatively low solubility in most solvents, very few quantitative data have been reported on the solubility of these compounds. Table 1 lists solubility data for $p$-tert butyl calix(n)arenes $(n=4,8)$ in various solvents at $298.15 \mathrm{~K}$.

TABLE 1. Solubilities, free energies of solution of p-tert butyl calix(n)arenes $(n=4,8)$ in various solvents at $298.15 \mathrm{~K}$. Derived transfer free energies.

\section{Solvent a \\ p-tert butyl calix(4)arene Solubility $/ \mathrm{mol} \mathrm{dm} \mathrm{dm}^{-3}$ b}

$\mathrm{MeOH}$

EtOH

DMF

AN

n-Hex

$\mathrm{CHCl}_{3}$

$\mathrm{C}_{6} \mathrm{H}_{5} \mathrm{CN}$

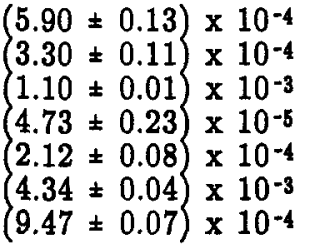

\section{$\Delta_{\mathbf{g}} \mathbf{G}^{*} / \mathbf{k J m o l}-\mathbf{l}$}

18.43

19.87

16.89

24.69

20.97

13.48

17.26

\section{$\Delta_{\mathrm{t}} \mathrm{G}^{\bullet} / \mathrm{kJmol}^{-1}$}

-6.26
-4.82
-7.80
0
-3.72
-11.21
-7.43

p-tert butyl calix(8)arene

$\begin{array}{llcr}\mathrm{MeOH} & <10^{-5} & - & - \\ \mathrm{EtOH} & <10^{-5} & - & - \\ \mathrm{DMF} & 2.20 \times 10^{-3} & 15.17 & -12.09 \\ \mathrm{AN} & 1.68 \times 10^{-5} & 27.26 & 0 \\ \mathrm{n}-\mathrm{Hex} & 2.51 \times 10^{-5} & 26.26 & -1.00 \\ \mathrm{CHCl}_{3} & 6.23 \times 10^{-3} & 12.59 & -14.67 \\ \mathrm{C}_{6} \mathrm{H}_{5} \mathrm{CN} & 1.14 \times 10^{-2} & 11.09 & -16.17\end{array}$

aAbbreviations: $\mathrm{MeOH}$, methanol; EtOH, ethanol; DMF, N,Ndimethylformamide; AN, acetonitrile; $\mathrm{n}-\mathrm{Hex}$, hexane; $\mathrm{CHCl}_{3}$, chloroform; $\mathrm{C}_{6} \mathrm{H}_{5} \mathrm{CN}$, benzonitrile. 
From these data, the solution free energy, $\Delta_{\mathrm{S}} \mathrm{G}^{\circ}$ of these compounds in the various solvents at the same temperature are calculated. In most cases, low solubilities are observed, mainly attributed to the intensive intramolecular hydrogen bonding. Thus, for calix(4)arenes, $\mathrm{X}$-ray diffraction studies (ref.41) have shown that, in the solid state, this compound is found in its cone conformation 8 , where hydrogen bonding takes place between the phenolic

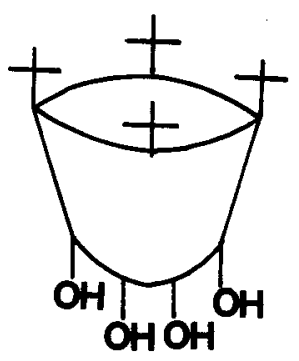

$\underline{8}$ groups in the lower rim of the molecule. When the number of phenol units increases, a flater conformation was found and calix(8)arene adopts a pleated loop structure where the distances between the oxygen groups of the phenolic group become shorter. As shown in table 1, solubilities of calix(8)arenes in the various solvents are lower than corresponding data for calix(4)arene in the same solvents. As a matter of interest, the solubility of these calix(n)arenes are compared with data for the monomer p-tert butyl phenol $\left(4.12 \mathrm{~mol} \mathrm{dm}^{-3}\right)$ in acetonitrile at $298.15 \mathrm{~K}$. A decrease in solubility by factors of $8.7 \times 10^{4}$ and $2.4 \times 10^{5}$ for the tetramer and octamer respectively with respect to the monomer is observed in these solvents. Taking acetonitrile as

the reference solvent, the transfer free energies, $\Delta_{t} G^{\circ}$ of these calixarenes to various solvents are calculated. The data reflect that, as far as these compounds are concerned, calix(n)arenes are better solvated in most solvents considered than in acetonitrile. However, the best solvators are benzonitrile, $\mathrm{N}, \mathrm{N}$ dimethylformamide (particularly for calix (8)arene) and chloroform. Although no studies have been carried out on the interaction of $p$-tert butyl calix(n)arenes with these solvents, the crystal structures of a number of complexes of $p$-substituted calix(n)arenes with neutral molecules have been reported (ref.42). It is likely that the larger solubilities observed in some of these solvents are due to their interactions with calix $(\mathrm{n})$ arenes. A more detailed thermodynamic study requires data on the contribution of the enthalpy and entropy to the transfer free energy of the process. However, the low solubility and in some cases, slow dissolution rates of these compounds in most of these solvents impeded us in carrying out calorimetric measurements of the heats of solution of calix(n)arenes. The recent advances in the design of a microcalorimetric system (ref.5) to determine enthalpies of solution of slightly soluble compounds open the possibility of carrying out these measurements in the near future.

\section{Calixarene derivatives}

An important development in the field of calixarene chemistry is the synthesis of chemically modified calixarenes obtained by functionalisation of the phenolic groups. Much of this work is due to the initiatives of Ungaro et al. (ref. 43). Chang et al. (ref. 44); McKervey et al. (ref. 45) and others. An up-to-date account on different aspects of calixarene derivatives can be found in the literature (ref. 46). As far as the thermodynamics of these systems are concerned, until recently most studies have been limited to stability constant measurements (refs. 47-50). In a chemical communication published in 1991 (ref. 18) we reported the first calorimetric studies of ethyl p-tert butyl calix(4)arene tetraacetate $6 \mathrm{a}$ and its metal ion complexes in acetonitrile and in methanol. The applications of calorimetry (macro and micro) to the study of host-guest interactions in solution have been recently discussed in (ref. 51). Some aspects of the research carried out in our laboratory on the thermodynamics of calixarene derivatives are now described. Whenever possible, these data will be compared with corresponding data for cryptands for which most of the enthalpy data for complexation and solution processes involving metal cations have been reported by us (refs. 6-9).

\section{Solubility of calix(4)erene esters}

Like parent calix(4)arenes, the esters contain a hydrophobic cavity lying between the aromatic rings and able to interact with neutral molecules. In addition, these compounds in their cone conformation are characterised by a second hydrophilic cavity $6 a$ and $b$, resulting from the encircling of oxygen atoms of the $-\mathrm{O}-\mathrm{CH}_{2}-\mathrm{C}<\mathrm{OR}$ groups and capable of forming metal ion complexes. Table 2 lists the solubilities of ethyl p-tert butyl calix(4)arene tetraacetate [EtCalix(4)] (ref. 18) and n-butyl p-tert butyl calix(4)arene tetraacetate [nButCalix(4)] (ref. 52) in methanol and in acetonitrile at $298.15 \mathrm{~K}$. 
TABLE 2. Solubilities, free energies of solution of calixarene esters in methanol and acetonitrile at $298.15 \mathrm{~K}$. Derived transfer free energies.

\begin{tabular}{|c|c|c|c|c|c|}
\hline Compound & $\longrightarrow$ Solubility $/ \mathrm{m}$ & $\mathrm{dm}^{-3} \longrightarrow$ & $-\Delta_{\mathrm{s}} \mathrm{G}^{0} / \mathrm{k}_{\mathrm{c}}$ & $\mathrm{mol}^{-1}$ & $\Delta_{\mathrm{t}} \mathrm{G}^{\circ} / \mathrm{kJmol}^{-1}$ \\
\hline 20 & $\mathrm{MeOH}$ & AN & $\mathrm{MeOH}$ & $\mathrm{AN}$ & $\mathrm{AN} \longrightarrow \mathrm{MeOH}$ \\
\hline$[\operatorname{EtCalix}(4)]$ & $(3.65 \pm 0.1) \times 10^{-3}$ & $(1.12 \pm 0.08) \times 10^{-2}$ & 13.91 & 11.13 & $2.78^{\mathrm{a}}$ \\
\hline [nButCalix(4)] & $(9.44 \pm 0.12) \times 10^{-3}$ & $(4.80 \pm 0.16) \times 10^{-2}$ & 11.56 & 7.53 & $4.00^{\mathrm{b}}$ \\
\hline
\end{tabular}

The data reflect that solubilities of calixarene esters are higher than those of parent calixarenes (table 1) in these solvents. This must be partially attributed to the inability of intermolecular hydrogen bond formation in the former relative to the latter macrocyclic compound. However, there are other factors to be considered such as the i) hydrophobic nature of the ester group. Thus, [nButCalix(4)] is more soluble by a factor of 3 to 4 relative to [EtCalix(4)] in these solvents. Therefore, for classical titration calorimetry, the former ligand is more suitable than the latter; particularly for low stability metal ion complexes.

ii) the nature of the solvent. From the two solvents considered, acetonitrile was found to be a better solvator for these ligands than methanol. However, a more detailed interpretation requires data for the enthalpic and entropic contribution to the free energy of these processes.

\section{Enthalpies and entropies of solution}

Representative data for the enthalpies and entropies of solution of calixarene esters in methanol and acetonitrile at $298.15 \mathrm{~K}$ are given. Table 3 lists $\Delta_{\mathrm{t}} \mathrm{H}^{\circ}$ and $\Delta_{\mathrm{t}} \mathrm{S}^{\circ}$ values for ethyl p-tert butyl calix(4)arene tetraacetate in these solvents.

TABLE 3 Enthalpies and entropies of solution of ethyl p-tert butyl calix(4)arene tetraacetate in methanol and acetonitrile at $298.15 \mathrm{~K}$. Derived parameters of transfer.

\begin{tabular}{|c|c|c|}
\hline \multicolumn{2}{|c|}{$\neg \Delta_{\mathrm{S}} \mathrm{H}^{\circ} / \mathrm{kJmol}^{-1} \longrightarrow$} & \multirow[t]{2}{*}{$\Delta_{\mathrm{t}} \mathrm{H}^{\bullet} / \mathrm{kJmol}^{-\mathrm{ta}}$} \\
\hline AN & $\mathrm{MeOH}$ & \\
\hline $22.67 \pm 0.17$ & $32.67 \pm 0.28$ & 10.00 \\
\hline \multicolumn{2}{|c|}{$\Delta_{\mathrm{s}} \mathrm{S}^{\bullet} / \mathrm{JK}^{-1} \mathrm{~mol}^{-1}$} & $\Delta_{\mathrm{t}} \mathbf{S}^{0} / \mathrm{JK}^{-1} \mathrm{~mol}^{-1}$ \\
\hline & 76.4 & 37.7 \\
\hline
\end{tabular}

aRef. 18; taking acetonitrile as the reference solvent.

Unlike transfer enthalpy and entropy data for cryptand 222(refs. 6-9); dibenzo cryptand 222 and dibenzo 18 crown 6 (refs 53 \& 54) among different solvents (except water) $\left(\Delta_{\mathrm{t}} \mathrm{H}^{\circ} \stackrel{N}{=}\right.$ $\left.0 \mathrm{kJmol}^{-1} ; \quad \Delta_{\mathrm{t}} \mathrm{S}^{\circ} \cong 0 \mathrm{JK}^{-1} \mathrm{~mol}^{-1}\right) ;$ corresponding data for [EtCalix(4)] (AN $\left.\rightarrow \mathrm{MeOH}\right)$ showed that this compound is enthalpically more stable (and entropically less favoured) in acetonitrile than in methanol. In fact, these results were atypical of the behaviour observed for the transfer of macrocyclic non-electrolytes and strongly suggested that a specific interaction between this ligand and acetonitrile was likely to take place (ref.18). Proton NMR data confirmed that this was indeed the case. $\mathrm{X}$-ray diffraction studies carried out by McKervey et al (ref.55) with a calix(4)arene tetracarbonate derivative revealed the formation of a 1:1 complex with acetonitrile in which the guest was hosted in the hydrophobic cavity of the calixarene molecule. On these bases, it was suggested that similar interactions take place between [EtCalix(4)] and acetonitrile and as a result, the hydrophilic cavity of the calixarene ester becomes better preorganised to interact with alkali metal cations in acetonitrile than in methanol. This was reflected in the higher stabilities (in terms of free energies and enthalpies) found for the complexation of [EtCalix(4)] with these cations (mainly $\mathrm{Li}^{+}, \mathrm{Na}^{+}$and $\mathrm{K}^{+}$) in the former solvent relative to the latter (ref.18). 
However, an interesting development that I could foresee was that an increase in the hydrophobicity of the solvent could increase the receptive properties of the hydrophobic cavity of this ligand toward the reaction medium, causing an allosteric effect which may alter more significantly than acetonitrile, the hosting abilities of the hydrophilic cavity for alkali metal cations. For these purposes, benzonitrile was selected as the reaction medium. A further advantage of using this solvent is that, unlike acetonitrile, a phase separation between benzonitrile and water can be achieved and therefore, this solvent system could be used for the extraction of alkali metal cations by calixarene esters. Our recent studies show that [EtCalix(4)] and [nButCalix(4)] are more highly soluble in benzonitrile than in acetonitrile (ref.52). In fact, for both ligands, solvate formation was detected when the solids were left in an environment saturated with benzonitrile vapours. However, the most striking results were found for the enthalpies of transfer of [EtCalix(4)] and [nButCalix(4)] from acetonitrile to benzonitrile (for those ligands $\Delta_{t} \mathrm{H}^{\circ} \cong-8 \mathrm{kJmol}{ }^{-1}$ ), which strongly suggest that the interaction of these ligands with benzonitrile is greater that their interaction with acetonitrile. The implications of these results on the thermodynamics of binding of alkali metal cations and [nButCalix(4)] in benzonitrile relative to acetonitrile are now discussed.

\section{Thermodynamics of complexation}

Fig. 1 shows the enthalpies of complexation of [nButCalix(4)] and alkali metal cations in acetonitrile and in benzonitrile at 298.15K. This ligand was chosen because of its higher solubility in acetonitrile relative to EtCalix(4)] (table 2), which enables the use of optimal concentrations of the metal ion salt and the ligand [as calculated by a computer simulation program (ref.56)] in the calorimetric runs and therefore, errors in the calculation of stability constant and enthalpy data are minimised. This figure unambiguously shows that (except for lithium), the complexation process is enthalpically more favoured in acetonitrile than in benzonitrile. For the former solvent an exothermic maximum is observed for sodium; while for the latter solvent, the highest enthalpic stability is found for lithium.

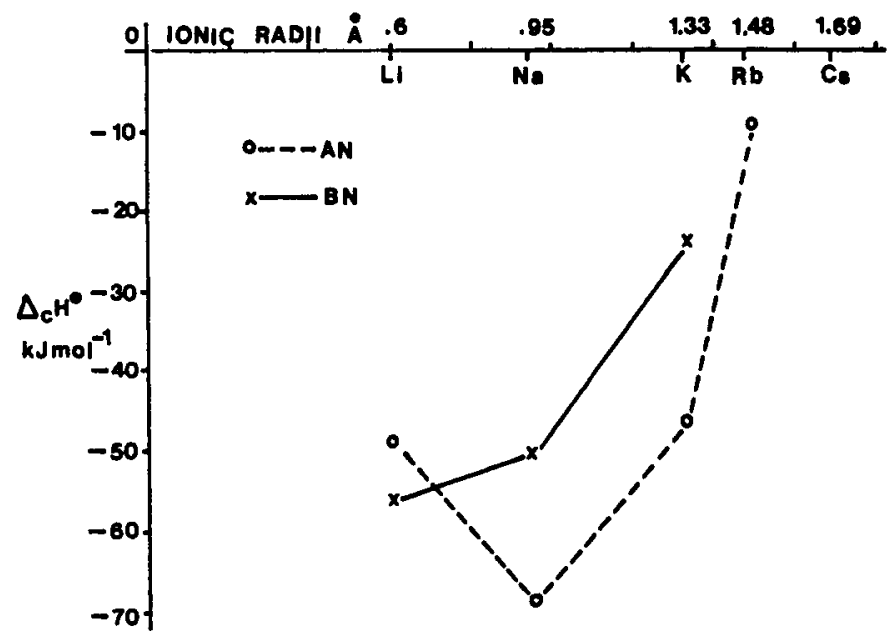

Fig. 1 Enthalpies of complexation of [nButCalix(4)] and metal cations in acetonitrile and in benzonitrile

We are now proceeding with conductance measurements in order to determine the stability constants $\left(\log K_{s}\right)$ as well as the ion-pair formation constants of the free and complexed cation with the anion in these solvents. The results in terms of enthalpies are striking, particularly in benzonitrile. In fact, these data are atypical of the thermodynamic behaviour observed for complexation reactions involving cryptands and alkali-metal cations in dipolar aprotic media. We have previously demonstrated (refs. 5-11) that for cryptands, the solvation of the cation plays a major role in these processes.

Benzonitrile is a poorer solvator for the cations than acetonitrile, a statement based on the thermodynamic parameters of transfer of these ions among these solvents (refs.57-58). Therefore, if cation solvation has a predominant role in binding processes involving calixarene esters in these solvents, a higher stability would be expected in benzonitrile than in acetonitrile. As illustrated in Fig.1, this pattern is only observed for lithium. For cations such as sodium and potassium, the opposite trend is found. The results seem to reflect that the interaction of $[\mathrm{nButCalix}(4)]$ with benzonitrile may differ from that in acetonitrile. The observation that in the former solvent the ligand discriminates against 
rubidium and caesium (complexation is not detected), while in acetonitrile only $\mathrm{Cs}^{+}$is not complexed by [nButCalix(4)] appears to indicate that the interaction with benzonitrile may cause a reduction in the size of the hydrophilic cavity to such an extent that this ligand in this reaction medium becomes more receptive for the smallest cation ( $\mathrm{Li}^{+}$) and unreceptive for the larger ones $\left(\mathrm{Rb}^{+}\right.$and $\left.\mathrm{Cs}^{+}\right)$. This is now being corroborated by ${ }^{13} \mathrm{C}$ NMR studies.

In enzymatic processes, an "allosteric" ligand has been defined as a molecule which binds to a site on an enzyme, which is distinct from the active centre, causing a conformational change which alters the kinetic properties of the enzyme (ref.59). On these bases, it is suggested that the terminology "allosteric guests" should be introduced in calixarene chemistry for molecules (for example, acetonitrile and benzonitrile) which are able to interact with the hydrophobic cavity of calixarene derivatives causing conformational changes which modify the selective properties of the hydrophilic cavity toward ionic guests.

We are now investigating the binding properties of several calixarene derivatives in several allosteric media and these results will be reported shortly.

\section{The effect of cyclodextrins on the transfer of drugs}

Cyclodextrins (7) are characterised by a hydrophobic cavity able to form inclusion complexes with a wide variety of guests (ref.60). A matter of current interest is the solubility enhancement observed for slightly soluble drugs by the addition of cyclodextrins (ref.61 \& 62). However, an important aspect of the bioavailability of a drug is that related to its transfer across the absorption barrier. Some research has been carried out on the transfer of drugs to a membrane like solvent such as chloroform (ref.63), but further research is required in order to make a quantitative assessment on the effect of cyclodextrins on the transfer of drugs from water to these solvents. In this context relevant parameters to be considered are:

i) the transfer free energy from water to a membrane like solvent $\left(\mathrm{Cl}_{3} \mathrm{CH}\right)$ for the drug (D);

$$
\mathrm{D}\left(\mathrm{H}_{2} \mathrm{O}\right) \stackrel{\Delta_{\mathrm{t}} \mathrm{G}^{\circ}}{\longrightarrow} \mathrm{D}\left(\mathrm{CHCl}_{3}\right)
$$

for the cyclodextrin (CD) molecule

$$
\mathrm{CD}\left(\mathrm{H}_{2} \mathrm{O}\right) \stackrel{\Delta_{t} \mathrm{G}^{\bullet}}{\longrightarrow} \mathrm{CD}\left(\mathrm{CHCl}_{3}\right)
$$

and for the drug-cyclodextrin complex (D-CD)

$$
\mathrm{D}-\mathrm{CD}\left(\mathrm{H}_{2} \mathrm{O}\right) \stackrel{\Delta_{t} \mathrm{G}^{\circ}}{\longrightarrow} \quad \mathrm{D}-\mathrm{CD}\left(\mathrm{CHCl}_{3}\right)
$$

ii) the free energy of complexation of the drug and the cyclodextrin in water and in chloroform

$$
\begin{aligned}
& \mathrm{D}\left(\mathrm{H}_{2} \mathrm{O}\right)+\mathrm{CD}\left(\mathrm{H}_{2} \mathrm{O}\right) \stackrel{\Delta_{\mathrm{c}} \mathrm{G}^{\bullet}}{\longrightarrow} \mathrm{D}-\mathrm{CD}\left(\mathrm{H}_{2} \mathrm{O}\right) \\
& \mathrm{D}\left(\mathrm{CHCl}_{3}\right)+\mathrm{CD}\left(\mathrm{CHCl}_{3}\right) \stackrel{\Delta_{\mathrm{c}} \mathrm{G}^{\bullet}}{\longrightarrow} \mathrm{D}-\mathrm{CD}\left(\mathrm{CHCl}_{3}\right)
\end{aligned}
$$

The drugs selected for our studies were $N^{1}$ substituted sulfonamides 9. Data for processes (1) (2) and (3) were derived from solubility measurements of the appropriate compounds in water and in chloroform. In water, corrections were made for the dissociation of sulfonamides in this solvent. For processes (4) and (5), complexation data were obtained by titration microcalorimetry. The key parameters to assess the effect of cyclodextrin on the transfer of drugs are those represented by eqns (3) and (5).

For process (3) we demonstrated (ref.20) that dissolution of the complex in chloroform led to values which were, in essence, the solubility value for the drug in chloroform. For process (5), no complexation was detected in this solvent. In addition, the transfer free energy of $\beta$ cyclodextrin $\left(\Delta_{t} G^{\circ}=16.29 \mathrm{kJmol}^{-1}\right)$ is a clear indication of the unfavourable character of the transfer process. The implication of these findings is that, in the presence 


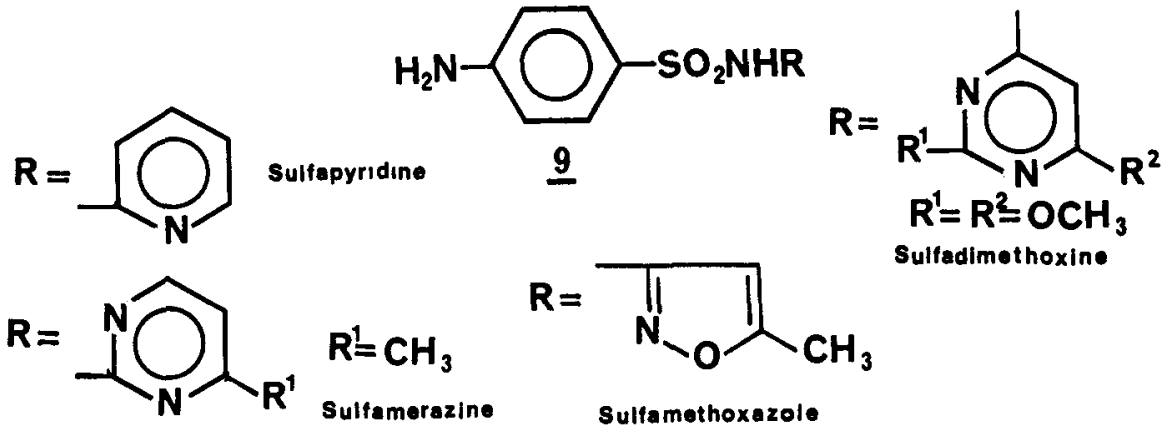

of cyclodextrin, the overall transfer constant $\mathrm{K}_{\mathrm{ex}}$ is predominantly controlled by two steps.

i) The dissociation of the complex in water

$$
\text { D-CD }\left(\mathrm{H}_{2} \mathrm{O}\right) \longrightarrow \mathrm{D}\left(\mathrm{H}_{2} \mathrm{O}\right)+\mathrm{CD}\left(\mathrm{H}_{2} \mathrm{O}\right)
$$

which is the reverse process to that shown by eqn (4)

ii) The transfer of the drug from water to chloroform (eqn 1).

Therefore $\mathrm{K}_{\mathrm{ex}}=\frac{1}{\mathrm{~K}_{\mathrm{S}}} \times \mathrm{K}_{\mathrm{t}}$, where $\mathrm{K}_{\mathrm{s}}$ and $\mathrm{K}_{\mathrm{t}}$ are the equilibrium thermodynamic constants for processes (4) and (1); respectively.

Some representative values for $K_{t}$ and $K_{e x}$ are shown in table 4 .

TABLE 4. Transfer $\left(K_{t}\right)$ and extraction $\left(K_{e x}\right)$ constants for $N^{1}$ substituted sulfonamides in the water-chloroform solvent system at $298.15 \mathrm{~K}$

\begin{tabular}{lcl|lrl} 
Compound & $\mathbf{K}_{\mathbf{t}^{\mathbf{a}}}$ & $\mathbf{K}_{\mathbf{e x}} \mathbf{a}$ & Compound & $\mathbf{K}_{\mathbf{t}}{ }^{\mathbf{a}}$ & $\mathbf{K}_{\mathbf{e x}} \mathbf{a}^{\mathbf{a}}$ \\
Sulfapyridine & 0.75 & $1.1 \times 10^{-3}$ & Sulfadimethoxine & 44.22 & $7.2 \times 10^{-2}$ \\
Sulfamethoxazole & 4.77 & $8.1 \times 10^{-3}$ & Sulfamerazine & 2.10 & $6.2 \times 10^{-3}$ \\
a ref.20 & & & & & \\
\hline
\end{tabular}

The results shown in this table unambiguously demonstrate that $K_{t}>K_{e x}$ and therefore, from the thermodynamic viewpoint, the drug is more favourably transferred in the absence of cyclodextrin than in its presence. This is now being studied at other temperatures. The kinetics of the process must be also considered but we have not yet reached that step.

\section{MACROCYCLIC LIGANDS FOR THE DESIGN OF NEW MATERIALS}

Our final goal is the use of "Macrocyclic Ligands for the Design of New Materials" for environmental, extraction and recognition purposes. At present we are carrying out the fundamental research which is required to explore later on the possibility of introducing environmentally friendly polymeric materials containing macrocyclic ligands as anchor groups as:

a) an alternative to current methodology used for metal extraction which requires the use of large quantities of non-aqueous solvents;

b) extracting agents for the removal and control of polluting ions and molecules from the environment.

The First International Symposium on "Macrocyclic Ligands for the Design of New Materials" will take place at the University of Surrey on 14-16 September 1992 and it is being organised by the European-Latin American Research Group (ELARG) in this area. Some of the results so far obtained by our group are to be presented at this Symposium. 


\section{FINAL REMARKS}

As mentioned earlier, the fascinating developments in the field of Supramolecular Chemistry have generated a very wide variety of electrolytes and non-electrolytes which await thermodynamic characterisation. This task should be undertaken by experts in the field. The subject is too appealing and cannot be dismissed. These new chemical entities, are, in essence, the outcome of the chemical evolution which was initiated in the late sixties and has grown extensively ever since. There are no doubts that the field of macrocyclic chemistry has contributed significantly to the solubility phenomena. There is a lot to be done on the physicochemical properties of these novel compounds. These data are needed. Initiatives geared to motivate young scientists to gain expertise in this area should be considered.

\section{Acknowledgements}

I am grateful to all of those who have contributed to this research. Their names appear in the list of references. Particular thanks are due to Professor M A McKervey for providing some of the samples of Et Calix(4) used in this work. This compound is now synthesised in our laboratory. The financial support provided by the Economic European Community (International Cooperation) and ICI are gratefully acknowledged.

\section{REFERENCES}

1. J.M. Lehn, Angew Chem. Int. Ed. Engl. 27, 89 (1988).

2. J.J. Christensen, D.J. Eatough, R.M. Izatt, Chem. Rev. 74, 351 (1974).

3. R.M. Izatt, J.S. Bradshaw, S.A. Nielson, J.D. Lamb and J.J. Christensen, Chem. Rev. 85,279 (1985).

4. R.M. Izatt, K. Pawlak, J.S. Bradshaw and R.L. Bruening, Chem. Rev. 91, 1721 (1991).

5. D. Hallén and I Wadsö, Pure and Appl. Chem. 61, 123 (1989).

6. A.F. Danil de Namor and L. Ghousseini, J. Chem. Soc., Faraday Trans. 81, 781 (1985).

7. A.F. Danil de Namor, J. Chem. Soc., Faraday Trans. I. 84, 2441 (1988).

8. A.F. Danil de Namor, Pure and Appl. Chem. 62, 2121 (1990).

9. A.F. Danil de Namor, R. Traboulssi and D.F.V. Lewis, J. Amer. Chem. Soc. 112, 8442 (1990).

10. A.F. Danil de Namor, R. Traboulssi and M. Salomon, J. Chem. Soc., Faraday Trans I, $86,2193(1990)$.

1.1. A.F. Danil de Namor, R. Traboulssi and D.F.V. Lewis, J. Chem. Soc., Chem. Comm. $751(1990)$.

12. I. Tabushi, Y. Taniguchi and H. Kato, Tetrahedron, 12, 1049 (1977).

13. A.F. Danil de Namor, J. Sueros Velarde, J. Cardenas Garcia, K.B. Nolan and B.G. Cox, unpublished results and A.F. Danil de Namor, Chemistry International, Vol. 13, No. 6219 (1991).

14. A.F. Danil de Namor, M. Llosa Tanco and M. Salomon, work in progress.

15. A.F. Danil de Namor, M.T. Garrido Pardo, L. Muñoz, D.A. Pacheco Tanaka, J.Sueros Velarde and M.C. Cabaleiro, J. Chem. Soc., Chem. Comm. 855 (1992).

16. A.F. Danil de Namor, P.M. Blackett and D.A. Pacheco Tanaka, work in progress.

17. A.F. Danil de Namor, D.A. Pacheco Tanaka and C.Y. Ng, work in progress.

18. A.F. Danil de Namor, N. Apaza de Sueros, M.A. McKervey, G. Barrett, F. Arnaud Neu and M.J. Schwing-Weill, J. Chem. Soc., Chem. Comm. 1546 (1991).

19. A.F. Danil de Namor,D.A. Pacheco Tanaka, J. Cárdenas García, M.C. Cabaleiro, B.M. Vuano, N. Rodríguez and O. Pieroni, work in progress.

20. A.F. Danil de Namor,D.A. Pacheco Tanaka, L. Nuñez Regueira, I. Gómez Orellana, J. Chem. Soc., Faraday Trans. 88, 12, 1665 (1992).

21. A.F. Danil de Namor and P.M. Blackett, work in progress.

22. A. von Baeyer, Ber. Dtsch. Chem. Ges. 5, 25, 280, 1096 (1872).

23. A. Zinke and E. Ziegler, Ber. 77B, 264 (1944).

24. C.D. Gutsche and R. Muthukrishnan, J. Org. Chem 43, 4905 (1978).

25. C.D. Gutsche, B. Dhawan, K.H. No and R. Muthukrishnan, J. Am. Chem. Soc 103, $3782(1981)$.

26. C.D. Gutsche in 'Calixarenes', Monographs in Supramolecular Chemistry, Fraser Stoddart, Royal Society of Chemistry (1989).

27. R.M. Izatt, J.D. Lamb, R.T. Hawkins, P.R. Brown, S.R. Izatt and J.J. Christensen, J. Am. Chem. Soc., 1051782 (1983).

28. S.R. Izatt, R.T. Hawkins, J.J. Christensen and R.M. Izatt, J. Am. Chem. Soc., 10763 (1985)

29. M.M. Olmstead, G. Sigel, H. Hope, X. Xu and P.P. Power, J. Am. Chem. Soc., 107 8087 (1985).

30. S.G. Bott, A.W. Coleman and J.L. Atwood, J. Chem. Soc., Chem. Comm. 610 (1986) and J.Am. Chem. Soc. 108, 1709 (1986) and 110,610 (1988). 
31. B.M. Furphy, J. M Harrowfield, D.L. Kepert, B.W. Skelton, A.H. White and F.R. Wilner, Inorg. Chem. 26, 4231 (1987).

32. B.M. Furphy, J.M. Harrowfield, M.I. Ogden, B.W. Skelton, A.H. White and F.R. Wilner, J. Chem. Soc., Dalton Trans. 2217 (1989).

33. L.M. Englehart, B.M. Furphy, J.M. Harrowfield, A.H. White and F.R. Wilner, Aust. J. Chem. 41, 1465 (1988).

34. G.D. Andreeti, G. Calestani, F. Ugozzoli, A. Arduini, E. Ghidini and R. Ungaro, J. Incl. Phenom. 5, 123 (1987).

35. G.E. Hofmeister, F.E. Hahn and S.F. Pedersen, J. Am. Chem. Soc. 111, 2318 (1989).

36. G.E. Hofmeister, E. Alvarado, J.A. Leary, D.I. Yoon and S.F. Pedersen, J. Am. Chem. Soc. $112,8843(1990)$.

37. J.M. Harrowfield, M.I Ogden, W.R. Richmond and A.H. White, J. Chem. Soc. Chem. Comm. 1159 (1991).

38. J.M. Harrowfield, M.I Ogden, and A.H. White, J. Chem. Soc. Dalton 979 (1991).

39. Z. Asfari, J.M. Harrowfield, M.I. Ogden, J. Vicens and A.H. White, Angew. Chem. Int. Ed Engl. 30, 854 (1991).

40. J.L. Atwood, G. William Orr, F. Hamada, R.L. Vincent, S.G. Bott and K.D. Robinson, J. Amer. Chem. Soc. 119, 2760 (1991).

41. M. Perrin and D. Oehler in Topics in Inclusion Phenomena, 'Calixarenes. A Versatile Class of Macrocyclic Compounds'. Ed J. Vicens and V. Böhmer, Kluwer Academy, 65 (1990).

42. G. Andreeti and F. Ugozzoli in Topics in Inclusion Phenomena, 'Calixarenes. A Versatile Class of Macrocyclic Compounds'. Ed J. Vicens and V. Böhmer, Kluwer Academy, 87 (1990).

43. A. Arduini, A. Pochini, S. Reverber and R. Ungaro, J. Chem. Soc., Chem. Comm. 981 (1984).

44. S. Chang and I. Cho, Chem. Lett. 477 (1984).

45. M.A. McKervey, E.M. Seward, G. Ferguson, B. Ruhl and S.J. Harris, J. Chem. Soc., Chem. Comm. 388 (1985).

46. R. Ungaro and A. Pochini (127) and M.J. Schwing-Weill and M.A. McKervey (149) in Topics in Inclusion Phenomena, 'Calixarenes. A Versatile Class of Macrocyclic Compounds'. Ed J. Vicens and V. Böhmer, Kluwer Academy (1990).

47. D.N. Reinhoudt, D.R. Dijkstra, P.J.A. in't Veld, K.E. Bugge, S. Harkema, R. Ungaro and E. Ghidini, J. Amer. Chem. Soc. 109, 4761 (1987).

48. F. Arnaud Neu, E.M. Collins, M. Deasy, G. Ferguson, S.J. Harris, B. Kaintner, A.J. Lough, M.A. McKervey, E. Marques, B.L. Ruhl, M.J. Schwing-Weill and E.M. Seward, J. Amer. Chem. Soc. 111, 8681 (1989).

49. P.J. Dijkstra, A.J. Brunink, K.E. Bugge, D.N. Reinhoudt, S. Harkema, R. Ungaro, F. Ugozzoli and E. Ghidini, J. Amer. Chem. Soc. 111, 7567 (1989).

50. F. Arnaud Neu, M.J. Schwing-Weill, K. Zidt, S. Cremin, S.J. Harris and M.A. McKervey, New J. Chem. 15, 33 (1991).

51. A.F. Danil de Namor, Indian Journal of Technology, Special Issue on Microcalorimetry in the press (1992).

52. A.F. Danil de Namor, M.C. Cabaleiro, A.R. Casal, M.T. Garrido Pardo, B.M. Vuano, $N$. Rodriguez and $O$. Pieroni, work in progress.

53. A.F. Danil de Namor, F.R. Fernandez and P. Greenwood, J. Chem. Soc., Faraday Trans I 83, 2663 (1987).

54. A.F. Danil de Namor and F.R. Fernandez, J. Chem. Soc., Faraday Trans I 84, 3539 (1988).

55. M.A. McKervey, E. Seward, G. Ferguson and B.L. Ruhl, J. Org. Chem. 51, 3551 (1986).

56. K. Ebert, H. Ederer, T.L. Isenhour, Computer Applications in Chemistry, V.C.H. Publishers, FRG (1989).

57. A.F. Danil de Namor and H. Berroa de Ponce, J. Chem. Soc., Faraday Trans I 89, 1569 (1987) and 84, 1671 (1988).

58. L. Ghousseini, PhD thesis University of Surrey (1985).

59. J.A. Ottaway 'Regulation of Enzyme Activity', Series Editors: Rickwood \& Male, IRL Press Ltd, UK (1988).

60. F. Cramer, W. Saenger and H. Ch. Spatz, J. Amer. Chem. Soc. 89, 14 (1967).

61. J. Szejtli, Molecular Entrapment and Release Properties of Drugs by Cyclodextrins; Controlled Drug Bioavailability ed V.F. Smolen and L.A. Ball, Wiley 365 (1985).

62. K.H. Frömming, Proc. First Internat. Symp. on Cyclodextrins, ed J. Szejtli, D. Reidel Publishing Co. 367 (1982).

63. K. Uekama, F. Hirayama, S. Nasu, N. Matsuo and T. Irie, Chem. Pharm. Bull (Tokyo) 26 (11), 3477 (1978). 